\title{
EFFECTS OF ALUMINUM SULFATE AND POLYELECTROLYTE SOLUTIONS ON THE GEOTECHNICAL PROPERTIES OF ORGANIC CLAY
}

\author{
BRENDAN C. O'KeLLYi)
}

\begin{abstract}
This paper presents the effects of dilute polyelectrolyte solution used in combination with aluminum sulfate on the geotechnical properties of a homogeneous high-plasticity organic clay derived from the purification of turbid water. Apart from the chemical additives, the alum-polyelectrolyte clay (APC) and untreated clay were similar in composition, comprising $41 \%$ micro-fibrous amorphous organic solids by dry mass. However, the geomechanical behavior of the APC material was enhanced by polymer-particle bridging phenomenon, which contributed to higher stress-strain modulus, $10-20 \%$ greater shear strength in undrained triaxial compression, a higher effective angle of shearing resistance value, reduced compressibility and a slower rate of consolidation compared to the untreated clay. Hence, this study raises the possibility of using dilute polyelectrolyte solution in combination with aluminum sulfate as an alternative soil improvement measure for organic residues and ultra-soft organic clay deposits.
\end{abstract}

Key words: chemical, clay, consolidation, highly organic soil, polymer, shear strength, slurry, soil stabilization (IGC: D10)

\section{INTRODUCTION}

This paper presents the effects of aluminum sulfate and polyelectrolyte solutions on the geotechnical properties of amorphous organic clay. Dilute polyelectrolyte and aluminum sulfate solutions are commonly used, for example, in the production of potable water by treating naturally occurring water at municipal works. Chemically-assisted sedimentation processes used in water purification reduce suspended solids, color, other soluble materials of organic origin and soluble metals to acceptable levels (Twort et al., 2000). Some are removed directly and some indirectly through attachment or adsorption onto particulate matter. In this application, small doses of polyelectrolyte (synthetic long-chain organic chemicals) improve the settling characteristics of floc produced by the aluminum sulfate coagulant and increase the inherent strength of larger floc by polymer-particle bridging. Further polyelectrolyte dosing of the sludge occurs in advance of the thickening process and mechanical dewatering of the alum-polyelectrolyte clay (APC) residue byproduct (Chih Chao et al., 1997; Turchiuli and Fargues, 2004). The geotechnical and hydraulic properties of APC residues derived from municipal water-treatment works have been reported in detail by Wang et al. (1992), Wang and Tseng (1993), O’Kelly (2008b, 2010) and O'Kelly and Quille $(2009,2010)$. The aim of this paper is to study the effects of the aluminum sulfate and polyelectrolyte additives on the constitutive, short- and long-term shear strength and consolidation behavior of these dewatered, high organic content residues.

\section{TEST MATERIALS}

\section{Formation}

Untreated clay slurry and APC residue, which were similar in composition apart from the aluminum sulfate and polyelectrolyte that had been added to the latter, were obtained at different stages of the purification process at the Clareville municipal water treatment works, County Limerick, Ireland. High color, turbid water (typically 20-25 NTU) is sourced for the Clareville works from the lower Shannon; a low gradient river that runs for much of its course through karstified limestone, overlain by raised and riverine bogs, many of which have been harvested for peat over the years. Much of the turbidity and color in the water was likely to be attributed to amorphous organic material derived from peat. The untreated clay slurry was formed by allowing 22.5 liter drums of turbid source water that had been sampled from the primary sedimentation tanks at the treatment works to evaporate and settle under gravity, typically over a period of one month, at ambient temperature in the geotechnical laboratory (O'Kelly, 2010). The thickened clay residue was poured from the drums into trays and its water content was allowed to reduce by fan-assisted evaporation, again at ambient temperature, before the clay paste was mechanically dewatered using a consolidometer press to

i) BE, MEngSc, PhD, FTCD, CEng, CEnv, MICE, FIEI, Senior Lecturer, Department of Civil, Structural and Environmental Engineering, Museum Building, Trinity College Dublin, Dublin, Ireland (bokelly@tcd.ie).

The manuscript for this paper was received for review on October 20, 2009; approved on December 9, 2010.

Written discussions on this paper should be submitted before November 1, 2011 to the Japanese Geotechnical Society, 4-38-2, Sengoku, Bunkyo-ku, Tokyo 112-0011, Japan. Upon request the closing date may be extended one month. 
produce a saturated cake. Although more than $40 \%$ of the suspended solids in the drum samples were volatile, the fact that the catchment source mainly comprised natural saturated peat meant that the bulk of these solids were already in a near stable condition. Hence, any biological activity that may have occurred during the course of settling and dewatering the clay slurry in the laboratory would not have significantly altered the characteristics of its constituent solids.

Aqueous solutions of aluminum sulfate and Magnafloc ${ }^{\circledR}$ LT25 polyelectrolyte, which were manufactured by Chemifloc Ltd. (Ireland) and CIBA Specialty Chemicals Ltd. (UK) respectively, were rapidly mixed with the main flow of turbid water just before the clarification process at the Clareville works. Magnafloc ${ }^{\circledR}$ LT25 is a polyacrylamide, a copolymer of sodium acrylate and acrylamide, with a very high molecular weight of (10-15) $\times 10^{6}$ and is anionic to a slight extent in aqueous solution. The aluminum sulfate was supplied to the Clareville works in its hydrated form (i.e., $\left.\mathrm{Al}_{2}\left(\mathrm{SO}_{4}\right)_{3} 14 \mathrm{H}_{2} \mathrm{O}\right)$ and the total dosage at the municipal works was $60-100 \mathrm{mg}$ aluminum sulfate and $0.8-2.0 \mathrm{mg}$ polyelectrolyte per liter of source water, with these range of values reflecting the necessary adjustments in concentration which depended on the turbidity level.

The APC residue, which was the byproduct of the clarification treatment process, comprised $4.8 \%$ polyelectrolyte by dry solids mass, which was calculated on the basis of the annual production of potable water at the Clareville works, the mass of dry solids residue produced per annum and the mean polyelectrolyte dosage, i.e., 1.4 $\mathrm{mg} / \mathrm{l}$ source water, assuming that all of the polyelectrolyte that had been added during the treatment processes was ultimately retained in the APC residue.

\section{Physiochemical Properties}

Index and classification tests carried out in accordance with BS1377 (1990a) indicated that the APC residue and untreated clay material were similar, with very high values of liquid limit, plastic limit and adhesion limit, high plasticity and high loss-in-dry-mass on ignition (Table 1$)$. The water content $(w)$ was determined by oven drying the test specimens at $105 \pm 5^{\circ} \mathrm{C}$ over a 24 -hour period. Oxidation of the volatile solids was not significant at this drying temperature since the bulk of the organic fraction was already in a near stable condition (O'Kelly, 2004) and the polyelectrolyte additive only became unstable above $150^{\circ} \mathrm{C}$.

Figure 1 shows data for counts against diffraction angle, expressed in degrees-two-theta, from X-ray diffraction analysis carried out on both surface-dry and wet APC specimens. There was an increased background and noise in the data, a product of the organic material, particularly for the wet specimens. The high intensity peaks were interpreted as quartz and manganoan calcite (common catchment bedrock minerals present as colloids in the source water) when matched to the International Centre for Diffraction database although there was also the likelihood of other trace minerals, albeit at concentra-
Table 1. Properties of the test materials

\begin{tabular}{lcc}
\multicolumn{1}{c}{ Parameter } & Untreated clay & APC \\
\hline Polyelectrolyte (\% dry solids mass) & 0 & 4.8 \\
Liquid limit (\%) & 550 & 550 \\
Plastic limit (\%) & 280 & 260 \\
Plasticity index & 270 & 290 \\
Adhesion limit (\%) & 355 & 365 \\
Specific gravity of solids & 1.83 & 1.99 \\
Loss in dry mass on ignition (\%) & 41 & 45 \\
pH & 7.9 & 7.1 \\
\hline
\end{tabular}

Note: APC, alum-polyelectrolyte clay

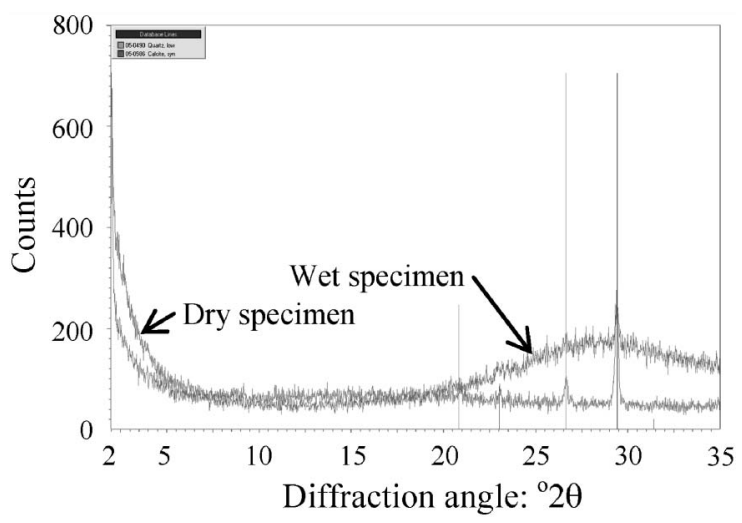

Fig. 1. X-ray diffraction analysis for alum-polyelectrolyte clay

tions of less than $1-2 \%$ by mass. The chemical additives did not feature since the alum precipitate was present in its amorphous aluminum hydroxide form (disordered and without any definable crystalline structure) and the polyelectrolytes are organic molecules.

The loss-in-dry-mass on ignition values of $45 \%$ and $41 \%$ for dry powdered APC and untreated clay, respectively, are a good reflection of their gravimetric organic contents since the crystalline fraction remained stable at the ignition temperature of $440^{\circ} \mathrm{C}$ (e.g., calcination occurs at a much higher temperature of about $850^{\circ} \mathrm{C}$ ). The $4 \%$ higher ignition-loss value measured for the APC was almost entirely due to the oxidation of its polyelectrolyte component (calculated earlier as $4.8 \%$ by dry mass), although its alum component also degrades at temperatures of $180-600^{\circ} \mathrm{C}$, and there was also the distinct possibility of some natural variation in the composition of the suspended solids in the source water, with the untreated clay suspension and APC residue having been sampled before the start and at the end of the clarification process respectively. Note that the constituent organic solids are predominantly micro-fibrous. The ash residue from the ignition tests was non-plastic indicating that the high plasticity was due to the organic fraction. The high organic content also accounts for the high water contents, low specific gravity of solids and very low bulk density and dry density values. Inductive-coupled plasma analysis of six specimens $(w=120-1100 \%)$ indicated that the APC comprised between $24 \%$ and $28 \%$ aluminum by dry mass, in line with the $29.7 \pm 13.3 \%$ reported for APC 
water-treatment residues by Babatunde and Zhao (2007). The aluminum hydroxide floc is insoluble over very narrow bands of $\mathrm{pH}$, with the optimum $\mathrm{pH}$ value for coagulation of lowland surface waters usually within the range of $\mathrm{pH}=6.5-7.2$. The $\mathrm{pH}$ value measured for the APC residue was near neutral since the alkalinity of the source water $(\mathrm{pH}=7.9)$ had been adjusted at the Clareville works by the addition of sulfuric acid, which also had the effect of enhancing the polyelectrolyte performance during the clarification process.

\section{EXPERIMENTAL METHOD}

\section{Undrained Shear Strength}

Unconsolidated undrained (UU) triaxial compression tests were carried out on 38-mm diameter by $76-\mathrm{mm}$ high specimens that had been prepared from one-liter standard Proctor samples compacted over the water content range of $200 \%$ to $400 \%$ in order to compare the shortterm shear strength of the different materials. Since intact triaxial specimens could not be easily prepared from material that had been standard Proctor compacted below about $200 \%$ water content, some of the wet triaxial specimens were allowed to stand in the geotechnical laboratory, slowly air dry and shrink without cracking in order to reduce the specimen water content value below $200 \%$ prior to shearing, thereby allowing shear strength data to be obtained for a wider water content range. These partially-saturated triaxial specimens were sheared quickly at $2 \%$ axial strain/min under a cell confining pressure of $100 \mathrm{kPa}$.

Two UU triaxial compression tests were also carried out on saturated physically-identical triaxial specimens using the same cell confining pressure of $260 \mathrm{kPa}$ but at different shearing rates in order to study the effects of shearing rate and creep on the undrained shear strength. Specimens A and B, $38 \mathrm{~mm}$ in diameter by $76 \mathrm{~mm}$ high, were prepared from a saturated APC cake that had been consolidated one-dimensionally and allowed to equilibrate under an applied vertical stress of $60 \mathrm{kPa}$ in a consolidometer apparatus. In these UU triaxial tests, specimen A was sheared quickly at $2 \%$ axial strain $/ \mathrm{min}$ whereas specimen $B$ was sheared much slower at $3.3 \times$ $10^{-5} \%$ axial strain/min in order for full equilibration of the excess pore water pressure to occur in the latter at shear failure.

\section{Effective Stress Shear Strength Properties}

The $c^{\prime}$ and $\phi^{\prime}$ parameter values were determined from isotropic consolidated-undrained (ICU) triaxial compression tests on $38-\mathrm{mm}$ diameter by $76-\mathrm{mm}$ high specimens, and with continuous measurement of the pore water pressure response, in order to compare the effective stress shear strength properties of the different materials. The triaxial specimens were prepared from saturated cakes of the APC and untreated clay that had been consolidated from the slurry state using the consolidometer apparatus.

The repeatability of the triaxial test procedure was studied by comparing the data from three physicallyidentical APC specimens, C-E, which were tested under the same conditions of effective stress, drainage and shearing rate. These triaxial specimens, which were prepared from residue cake that had been allowed to equilibrate under an applied vertical stress of $60 \mathrm{kPa}$ in the consolidometer, were sheared slowly in undrained triaxial compression at $3.3 \times 10^{-5} \%$ axial strain $/ \mathrm{min}$.

The $c^{\prime}$ and $\phi^{\prime}$ parameter values for the APC and untreated clay were determined from a suite of ICU triaxial compression tests on specimens that had been prepared from two residue cakes consolidated under an applied vertical stress of $30 \mathrm{kPa}$ in the consolidometer. These triaxial specimens were allowed to drain radially to filterpaper side drains and from both ends over a 24-hour period under effective cell confining pressures of between 30 and $150 \mathrm{kPa}$, applied against a specimen back pressure $u_{\mathrm{b}}=200 \mathrm{kPa}$. All of the specimens were sheared in an undrained condition at $3.3 \times 10^{-5} \%$ axial strain $/ \mathrm{min}$, which was sufficiently slow for full equilibration of the pore water pressures to occur at shear failure (determined from standard curve-fitting analysis of the triaxial consolidation data to BS1377 (1990b)).

\section{Compressibility}

Saturated specimens of different size, aspect ratio and

Table 2. Summary of the consolidation tests

\begin{tabular}{|c|c|c|c|c|c|c|c|c|c|c|}
\hline \multirow{2}{*}{$\begin{array}{c}\text { Test } \\
\text { method }\end{array}$} & \multirow{2}{*}{$\begin{array}{l}\text { Dimensions }^{\mathrm{a}} \\
(\mathrm{mm})\end{array}$} & \multirow{2}{*}{ Consistency } & \multicolumn{2}{|c|}{ Water content } & \multirow{2}{*}{$\begin{array}{l}\text { Applied stress } \\
\qquad(\mathrm{kPa})\end{array}$} & \multicolumn{2}{|c|}{ Void ratio } & \multirow{2}{*}{$\begin{array}{l}\text { Stage } \\
\text { length } \\
\text { (day) }\end{array}$} & \multirow{2}{*}{$\begin{array}{l}\text { Compression } \\
\text { index: } C_{\mathrm{c}}\end{array}$} & \multirow{2}{*}{$\begin{array}{l}\text { Compression } \\
\text { ratio: } C_{\mathrm{c}}^{*}\end{array}$} \\
\hline & & & $\begin{array}{c}\text { Initial } \\
(\%)\end{array}$ & $\begin{array}{c}\text { Final } \\
(\%)\end{array}$ & & Initial & Final & & & \\
\hline \multicolumn{11}{|l|}{ Oedometer } \\
\hline APC & $76 \times 29$ & Slurry & 700 & 230 & $\sigma_{\mathrm{v}}=3-200(\mathrm{MI})$ & 14.1 & 4.4 & 2 & 2.5 & 0.17 \\
\hline \multicolumn{11}{|l|}{ Consolidometer } \\
\hline Untreated clay & $152 \times 167$ & Slurry & 760 & 435 & $\sigma_{\mathrm{v}}=10-30(\mathrm{MI})$ & 15.4 & 8.1 & 7 & 5.5 & 0.34 \\
\hline $\mathrm{APC}$ & $152 \times 139$ & Slurry & 580 & 420 & $\sigma_{\mathrm{v}}=10-30(\mathrm{MI})$ & 10.9 & 8.4 & 7 & 3.1 & 0.26 \\
\hline \multicolumn{11}{|l|}{ Isotropic triaxial } \\
\hline Untreated clay & $38 \times 76$ & Very soft & 435 & 300 & $\sigma_{\mathrm{c}}^{\prime}=30-150(\mathrm{SI})$ & 8.1 & 5.6 & 1 & $2.3^{\mathrm{b}}$ & 0.25 \\
\hline $\mathrm{APC}$ & $38 \times 76$ & Very soft & 420 & 330 & $\sigma_{\mathrm{c}}^{\prime}=30-150(\mathrm{SI})$ & 8.4 & 6.6 & 1 & $1.7^{\mathrm{b}}$ & 0.18 \\
\hline
\end{tabular}

Note: MI, multiple increment; SI, single increment; $\sigma_{\mathrm{c}}^{\prime}$, effective cell confining pressure; $\sigma_{\mathrm{v}}$, applied vertical stress; primary compression ratio $C_{\mathrm{c}}^{*}=$ $C_{\mathrm{c}} /\left(1+e_{\mathrm{o}}\right)$ where $C_{\mathrm{c}}$, compression index; $e_{\mathrm{o}}$, initial void ratio

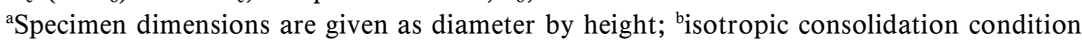




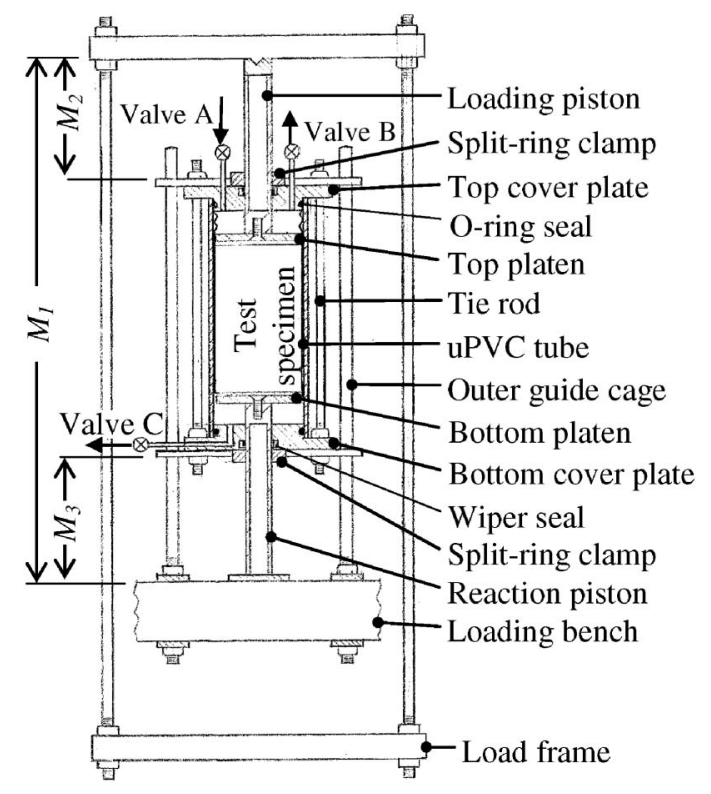

Fig. 2. Schematic of the consolidometer apparatus (O'Kelly, 2008a, 2009)

consistency were prepared from the remolded APC and untreated clay and compressed under different loading and drainage conditions in the consolidometer, oedometer and triaxial apparatus (Table 2).

In the floating-ring consolidometer setup (Fig. 2), the $152-\mathrm{mm}$ diameter confining cell can move vertically relative to the top and bottom platens, guided by an outer cage comprising four steel bars that are bolted to the loading bench. The specimens were prepared by simply pouring uniform slurry material into the confining cell, with vigorous roding to remove any air voids. Valves B and $C$ in the cell top and bottom cover plates were opened fully and maintained loads were applied using a load frame and lever system. Distances $M_{1}, M_{2}$ and $M_{3}$ (see Fig. 2) were continuously measured by displacement transducers during the course of a test, where $\Delta M_{1}$ is the specimen compression and $\Delta M_{1}=\Delta M_{2}+\Delta M_{3}$.

The oedometer and consolidometer tests were carried out over the applied stress range of 3 to $200 \mathrm{kPa}$ using a stress-increment ratio of unity, two-way drainage to atmosphere and load-stage durations of two and seven days, respectively, in order to record sufficient data covering both the consolidation and secondary compression responses for successive stress increments. The triaxial specimens were prepared from the pressed consolidometer cakes and isotropically consolidated over a 24-hour period, with specimen drainage allowed to occur radially and from both ends under an effective cell confining pressure in the range of $30-150 \mathrm{kPa}$, with $u_{\mathrm{b}}=200$ $\mathrm{kPa}$.

\section{EXPERIMENTAL RESULTS AND ANALYSIS}

\section{Undrained Shear Strength}

Figure 3 shows some deviator stress against strain data for pairs of APC and untreated clay specimens that had

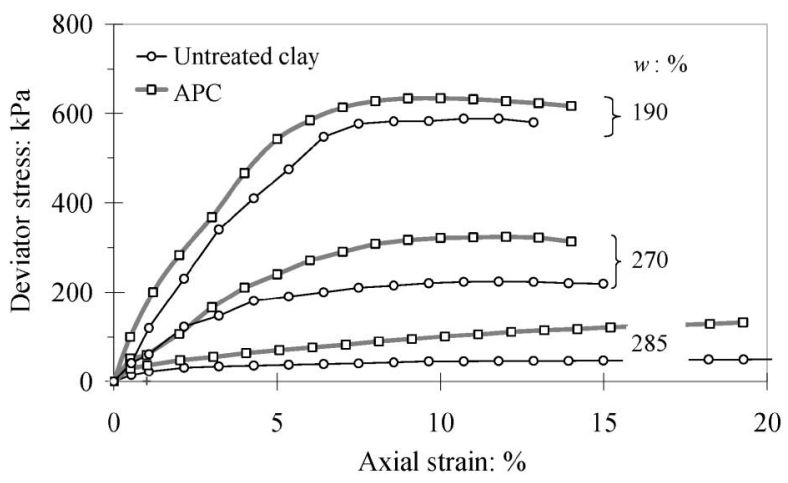

Fig. 3. Quick-undrained triaxial compression data for standard Proctor compacted specimens. Note: APC, alum-polyelectrolyte clay; deviator stress $=\sigma_{1}-\sigma_{3}$

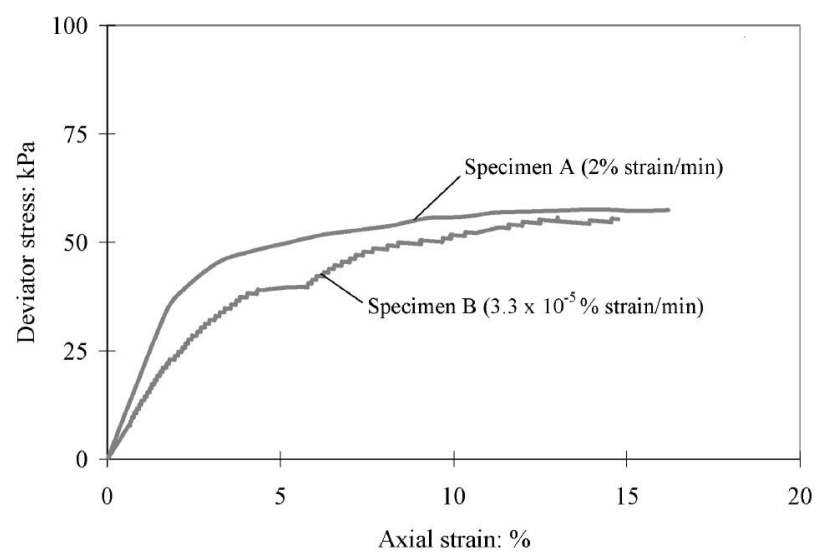

Fig. 4. Effect of shearing rate for saturated APC

been standard Proctor compacted at similar water contents in the range of $190-285 \%$ and sheared in UU triaxial compression. Note that the deviator stress, which equals the difference between the major and minor principal stresses, is induced by the axial load applied by the loading piston.

Figure 4 shows deviator stress against strain data for the two saturated and physically-identical APC specimens, $\mathrm{A}$ and $\mathrm{B}$, which were prepared wet of the plastic limit condition with $I_{\mathrm{L}}=0.14$, where $I_{\mathrm{L}}$ is the liquidity index. Specimen A experienced a stiffer response since it had been sheared at a strain rate five orders of magnitude greater than that used in shearing specimen B. However, undrained creep effects did not appear to be significant for the test material since both specimens were found to have similar undrained shear strengths despite the significant difference in shearing rate.

Figure 5(a) shows data of undrained shear strength against water content from the UU and ICU triaxial tests. Note that these shear strength values, calculated as half of the deviator stress, have been corrected for the restraining effect of the enclosing rubber membrane on the specimen deformation response and also the filter-paper drains that were used in the case of the ICU specimens (BS1377, 1990b). The ratio of the APC shear strength to the untreated-clay shear strength values measured for the 


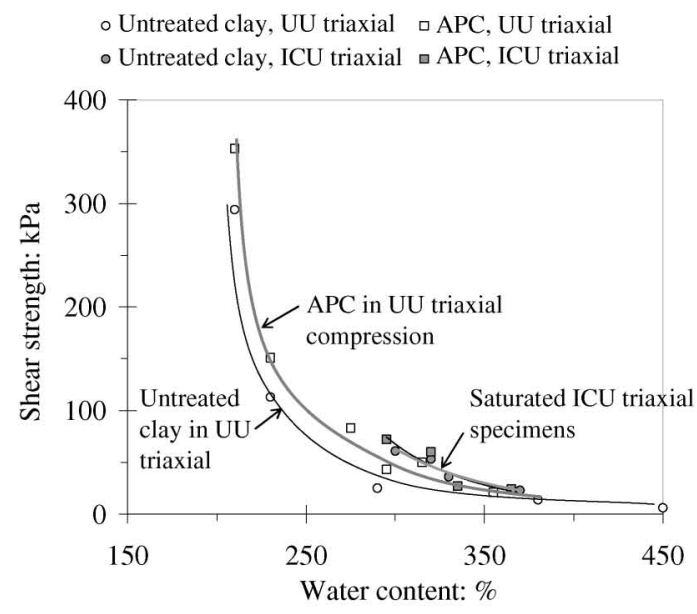

(a) Undrained shear strength against water content.

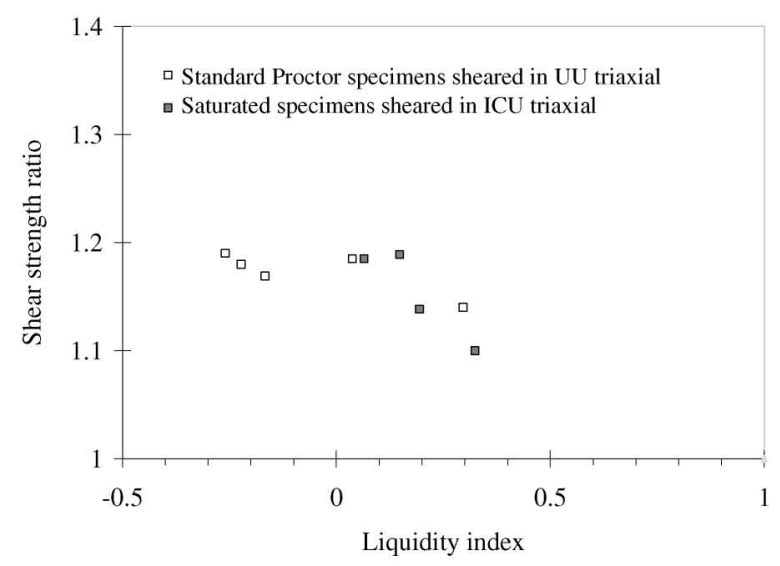

(b) Ratio of APC to untreated-clay shear strengths determined for the same water content.

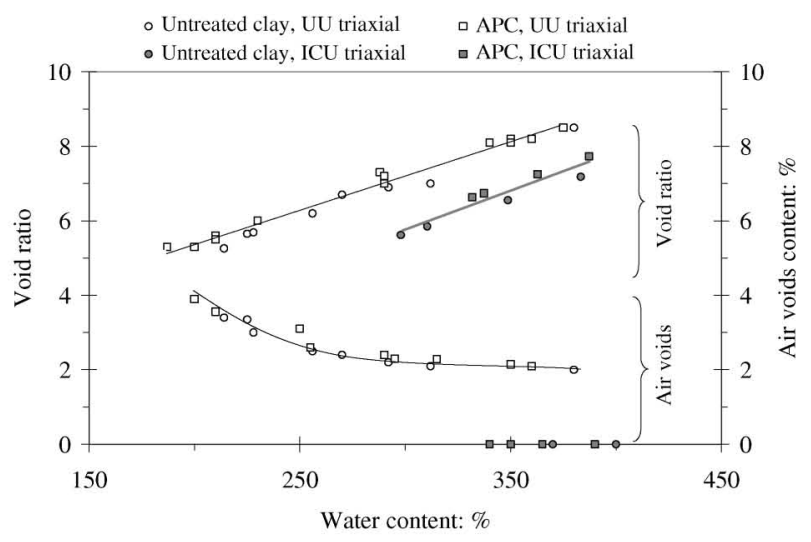

(c) Comparison of the specimen preparation methods.

Fig. 5. Undrained shear strength, $s_{\mathrm{u}}$, in triaxial compression. Note: $s_{\mathrm{u}}=\left(\sigma_{1}-\sigma_{3}\right) / 2$

same water content in undrained triaxial compression (see for example Fig. 3) are shown against liquidity index in Fig. 5(b). Note: liquidity index values of unity and zero correspond to the liquid limit and plastic limit conditions respectively. $I_{\mathrm{L}}<0$ indicates that the material was in a semisolid state. The undrained shear strength of the

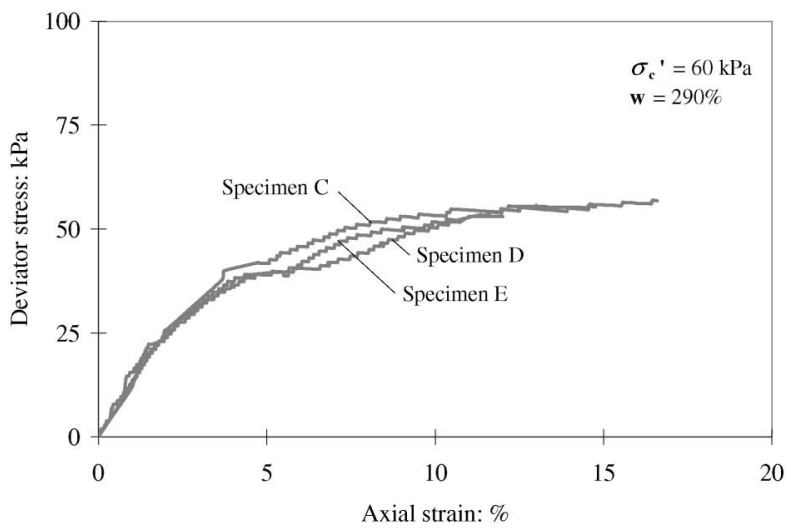

(a) Deviator stress against strain.

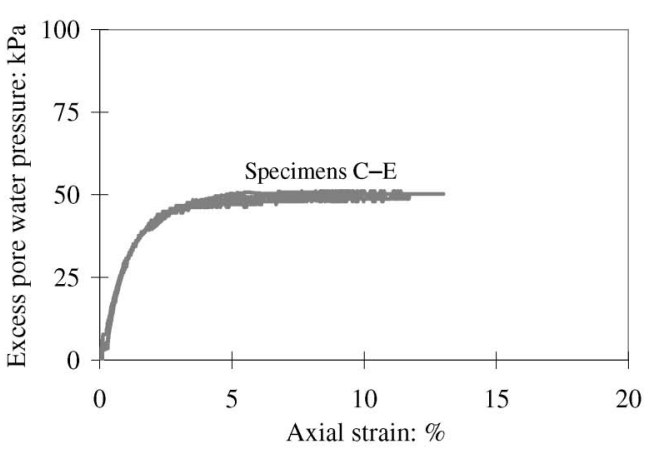

(b) Excess pore water pressure response.

Fig. 6. Repeatability of the ICU triaxial test procedure

APC was consistently between $10 \%$ and $20 \%$ greater than that measured for the untreated clay over the specimen water content range of $190 \%$ to $400 \%$ tested. Figure 5(a) also indicates that although the saturated ICU triaxial specimens has been sheared at considerably slower rates, their undrained shear strength at a given water content was marginally greater than that measured for the partially saturated UU triaxial specimens since the void ratio of the latter, with typically $2-4 \%$ air voids content, was always greater (Fig. 5(c)).

\section{Effective Stress Shear Strength Properties}

Figure 6 confirms that the repeatability of the ICU triaxial test procedure was very good, with the three physically-identical APC specimens, C-E, experiencing practically identical constitutive and excess pore water pressure responses under the same test conditions.

Figure 7 shows the deviator stress response corrected for specimen membrane and side drain effects (BS1377, $1990 \mathrm{~b})$, excess pore water pressure response and $t^{\prime}$ against $S^{\prime}$ effective stress path plots from the triaxial compression tests on saturated APC and untreated clay specimens. Note: $s^{\prime}=\left(\sigma_{1}^{\prime}+\sigma_{3}^{\prime}\right) / 2$ and $t^{\prime}=\left(\sigma_{1}^{\prime}-\sigma_{3}^{\prime}\right) / 2$ are the MIT effective stress path parameters: where $\sigma_{1}^{\prime}$ and $\sigma_{3}^{\prime}$ are the major and minor effective principal stresses respectively. Failure lines of best fit were drawn passing through the origin on the effective stress path plots, i.e., effective cohesion of zero for these normally consolidated specimens 


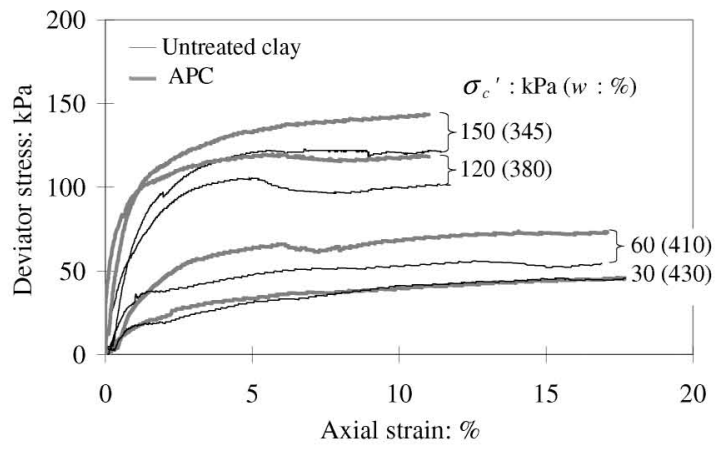

(a) Deviator stress against strain. Note: deviator stress $=\sigma_{1}-\sigma_{3}$.

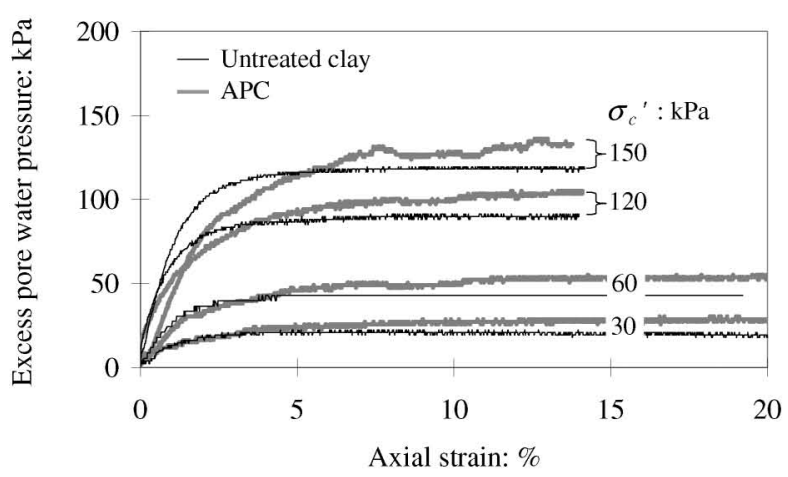

(b) Excess pore water pressure response.

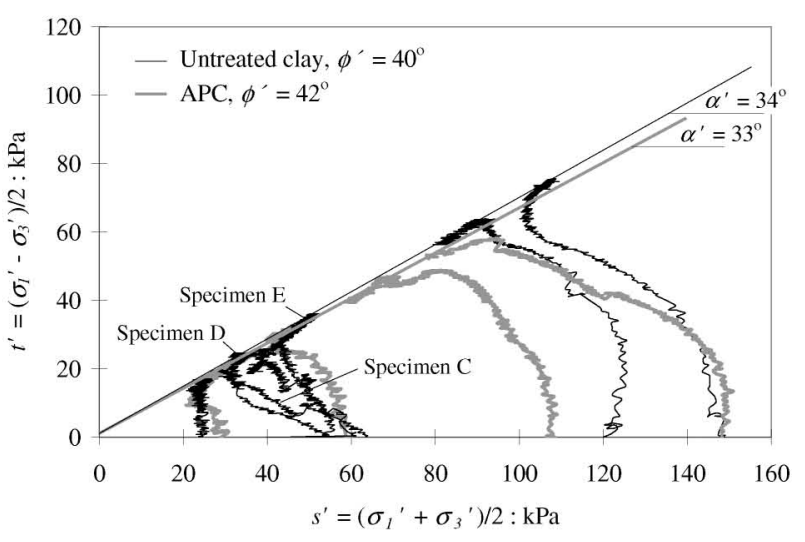

(c) Effective stress paths.

Fig. 7. ICU triaxial compression data

(Fig. 7(c)). Note that the effective stress paths at failure for the APC specimens, C-E, which had been sheared slowly at the same rate and with continuous measurement of the pore water pressure response, were also coincident with the APC failure line in Fig. 7(c). Since the APC specimens had higher stress-strain modulus and mobilized peak shear stresses of up to $20 \%$ greater under the same test conditions, the effective angle of shearing resistance $\left(\phi^{\prime}\right)$ value for the APC was also greater than that measured for the untreated clay, with $\phi^{\prime}=42^{\circ}$ and $40^{\circ}$ determined from the gradient $\left(\alpha^{\prime}\right)$ of the respective failure lines:

$$
\phi^{\prime}=\sin ^{-1}\left(\tan \alpha^{\prime}\right)
$$

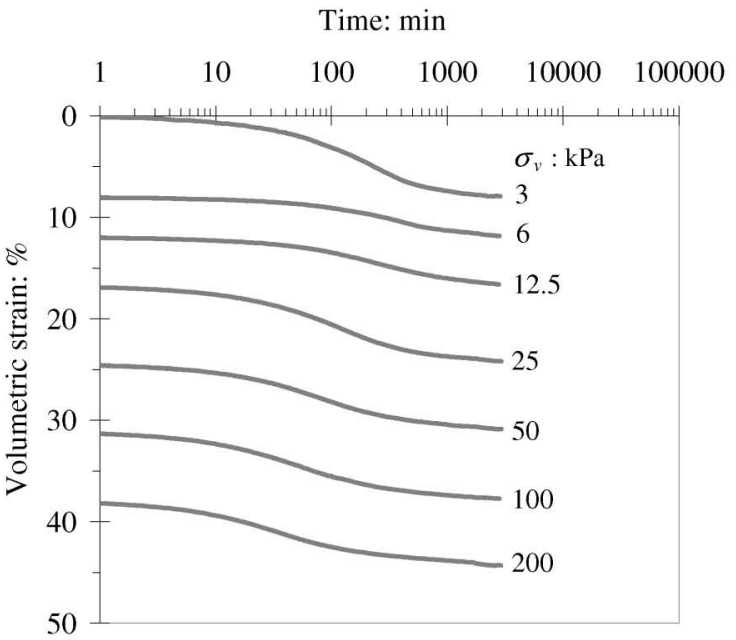

(a) APC slurry in oedometer.

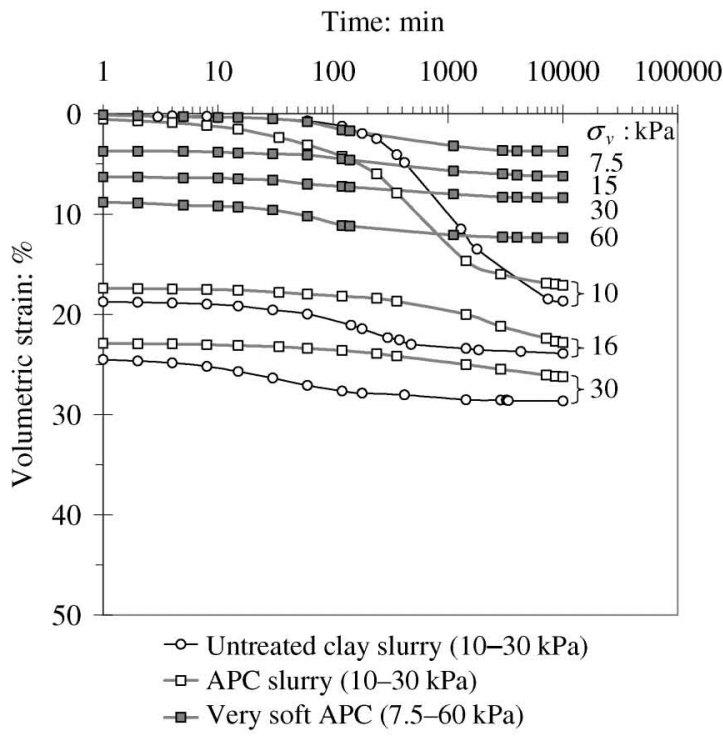

(b) Consolidometer.

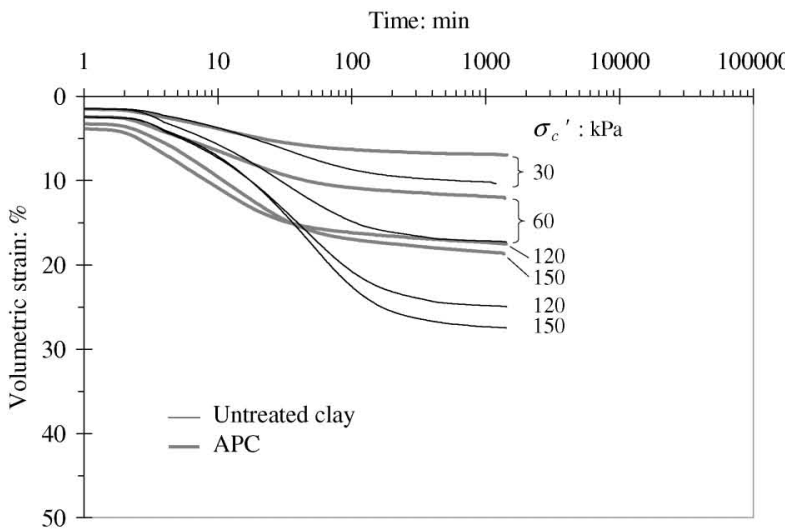

(c) Isotropic triaxial.

Fig. 8. Consolidation data

The ratio of the undrained shear strength in triaxial compression to the effective confining pressure applied during the consolidation stage was between 1.7 and 1.9 for both 


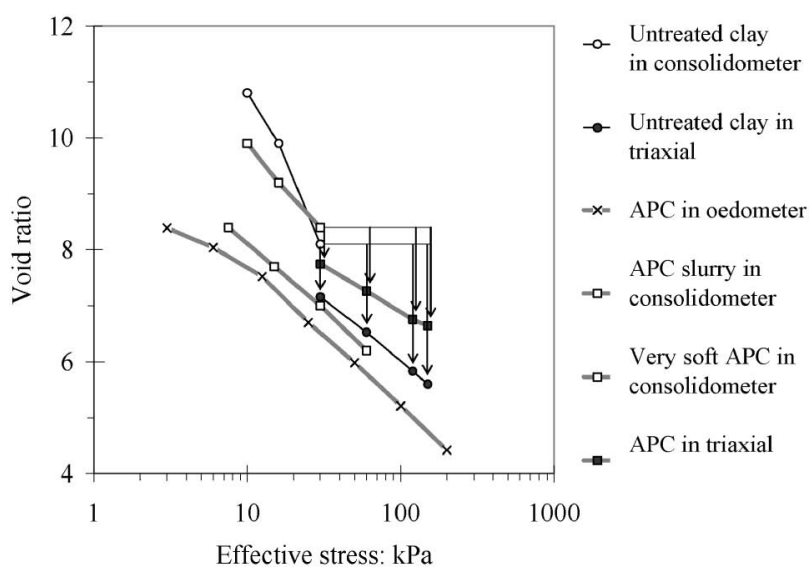

Fig. 9. Compressibility

the APC and untreated clay. The value of the pore pressure coefficient $A$ at failure was $0.7-1.0$, consistent with the behavior of normally consolidated clay.

\section{Compressibility}

Figure 8 shows volumetric strain against logarithm of time data for the slurry and very soft specimens of APC and untreated clay that had been consolidated using the oedometer, consolidometer and triaxial apparatus. The stress-strain-time data are summarized as void ratio against logarithm of effective stress in Fig. 9.

As expected, the saturated APC and untreated clay were highly compressible due to their high water and organic contents. However, the APC was less compressible and consolidated at a slower rate compared to the untreated clay. For example, APC and untreated clay of slurry consistency tested in the consolidometer apparatus had compression index values of $C_{\mathrm{c}}=3.1$ and 5.5 respectively (Table 2). APC and untreated clay of very soft consistency isotropically consolidated using the triaxial apparatus had values of $C_{\mathrm{c}}=1.7$ and 2.3 respectively. A comparison of the primary compression ratio $\left(C_{c}^{*}\right.$, Eq. (2)) values, which take into account the initial specimen consistency (void ratio), also indicated that the APC was less compressible than the untreated clay (Table 2):

$$
C_{\mathrm{c}}^{*}=\frac{C_{\mathrm{c}}}{1+e_{\mathrm{o}}}
$$

where: $e_{\mathrm{o}}$, initial void ratio.

Note that the level of compression depends on a range of factors (including initial water content/void ratio, specimen thickness, applied stress and drainage conditions, hydraulic conductivity, duration of the load stages) and explains the range in the compression index values listed in Table 2, which were determined for the same materials but using different test methods.

Standard curve-fitting analysis of the strain against logarithm of time responses for the APC and untreated clay in Fig. 8 indicated that primary consolidation was the dominant mechanism but that secondary compression became increasingly significant at higher stresses. Note that coefficient of secondary compression values of

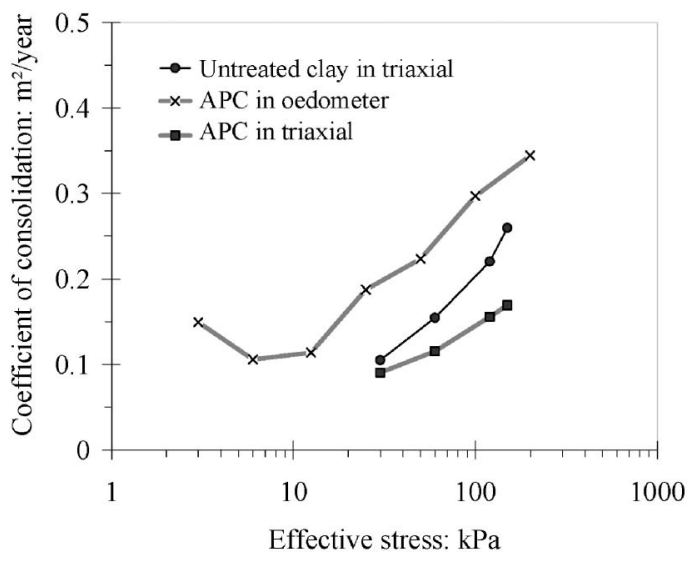

Fig. 10. Coefficient of consolidation data

$0.005-0.010$, calculated as the volumetric strain per tenfold increase in elapsed time after substantial completion of the primary consolidation phase in the oedometer tests, have been reported for the APC residue from the Clareville works by O'Kelly and Quille (2009) and O'Kelly (2010).

However, the rate of consolidation was slow, with coefficient of consolidation values of $0.10-0.35 \mathrm{~m}^{2} /$ year for $\sigma_{\mathrm{v}}^{\prime}=3-200 \mathrm{kPa}$ (Fig. 10) due to the very low hydraulic conductivity of the order of $10^{-9}$ to $10^{-10} \mathrm{~m} / \mathrm{s}$, which was calculated from the oedometer data in Fig. 8(a) using Terzaghi consolidation theory. This is consistent with the experience of mechanically dewatering the APC residue at the treatment works. A comparison of the triaxial data in Fig. 10 indicates that the coefficient of consolidation values for the APC were consistently lower than that for the untreated clay with the trend in the data suggesting that the difference in the consolidation behavior, and hence in hydraulic conductivity values, tends to increase with increasing effective stress.

\section{DISCUSSION}

\section{Role of Chemical Additives in Formation of APC Residue}

Clay in turbid water is a hydrophobic suspension in which individual colloids (about $0.01-1 \mu \mathrm{m}$ in size) usually have a net negative surface charge and the repelling forces of this electrical charge contribute to the stability of the solution by preventing the particles from coalescing into larger particles that would settle under gravity relatively rapidly. When aluminum sulfate solution is intensely mixed into turbid water, various species of positively-charged soluble aluminum hydroxide complexes form due to the reaction between this acidic coagulant and the natural alkalinity of the source water, which usually consists of calcium bicarbonate (Twort et al., 2000). In sufficient concentration, these mono- and poly-nuclear species adsorb onto the negatively charged colloids through a process of charge neutralization, destabilizing the colloidal suspension so that aluminum hydroxide floc formation and particle aggregation can occur due to par- 


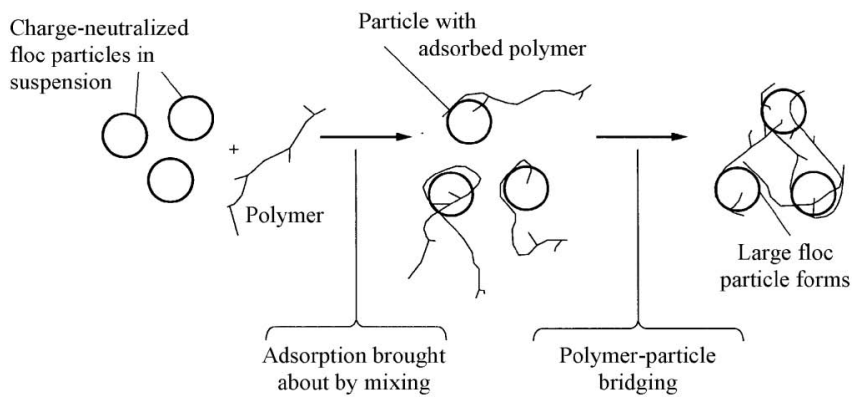

Fig. 11. Floc particle formed by polymer-particle bridging (adopted from Tchobanoglous et al. (2003))

ticle collisions brought about by Brownian motion. By continuously but gently mixing the water, these destabilized particles (which by this stage have grown to typically $1-10 \mu \mathrm{m}$ in size) are bound together by hydrogen bonding or van der Waals forces of attraction to form larger floc particles, as well as further particulate removal by entrapment into the flocs and by differential settling in which large floc particles sweep down, enmesh and coprecipitate colloidal particles, although the net force holding these particles together is weak and they are easily ruptured (Tchobanoglous et al., 2003). Polynuclear aluminum hydrolysis species and polyelectrolyte attach at a number of adsorption sites to the surface of the particles and a bridge is formed when two or more particles become adsorbed along the length of the polymer (Fig. 11).

Bridged particles become intertwined with many other bridged particles during the flocculation process and the size of the three-dimensional floc particles grows. Polyelectrolytes are effective even when they carry a charge the same sign as that of the colloids since flocculation aid by polyelectrolytes normally follows charge neutralization or bridging or both (Twort et al., 2000). The larger floc particles settle out more readily under gravity, removing not only the impurities but also most of the chemicals that had been added during the treatment process, producing the homogeneous APC residue byproduct.

\section{Effect of Chemical Additives on Geomechanical Proper- ties}

Apart from the chemical additives, the APC and untreated clay were similar in composition, comprising about $41 \%$ amorphous organic solids by dry mass, and hence any difference in mechanical behavior measured for the same water content value and under the same test conditions was most likely attributable to the affect of the chemical additives. Compared to the untreated clay, the APC was found to have a higher stress-strain modulus, $10-20 \%$ greater undrained shear strength in triaxial compression and hence a higher effective angle of shearing resistance value although the compressibility and rate of consolidation were lower. Although further studies at micro-scale level are necessary, it is postulated that in the case of the APC, the combined action of the polynuclear aluminum hydrolysis species and polyelectrolyte in inter- particle bridging, which results in the formation of larger and stronger floc, also produces greater inter-particle contact and a reduction in size of the internal pores and micro-channels of the floc particles themselves. Furthermore, the trivalent aluminum ion absorbs some of the internal water and the pore water in the voids between the floc particles (Wang and Tseng, 1993), which collectively contribute to a reduction in compressibility and the rate of consolidation.

In summary, polyelectrolytes are a unique class of polymer which find extensive application in the production of potable water, the treatment of industrial process water and municipal sewage sludge mineral processing and metallurgy, oil drilling and recovery, paper and board production, etc. This study raises the possibility of using dilute polyelectrolyte solution in combination with aluminum sulfate as an alternative soil improvement measure for high organic content residues and ultra-soft organic clay deposits. Furthermore, this chemical treatment may also reduce the hydraulic conductivity of such deposits which can have significant potential in practice; for example, in reducing the risks associated with the leachability of contaminated sediments.

\section{SUMMARY AND CONCLUSIONS}

The affects of dilute polyelectrolyte solution used in combination with aluminum sulfate on the geomechanical properties of a homogeneous high-plasticity organic clay derived from the purification of turbid water were studied using a range of geotechnical laboratory tests. Apart from the chemical additives, the alum-polyelectrolyte clay (APC) and untreated clay were similar in composition, namely $41 \%$ micro-fibrous amorphous organic solids by dry mass with the mineral fraction mainly comprising quartz and manganoan calcite.

Although index and classification tests indicated that the APC and untreated clay were similar, the geomechanical behavior of the APC, which comprised an additional $4.8 \%$ polyelectrolyte by dry mass, was enhanced with higher stress-strain modulus, $10-20 \%$ greater shear strength in undrained triaxial compression measured over a wide range of water contents, a greater effective angle of shearing resistance value, reduced compressibility and a slower rate of consolidation compared to the untreated clay.

In the case of the APC material, the constituent floc particles were much larger and stronger due to polymerparticle bridging phenomenon. Charge neutralization by adsorption, inter-particle bridging and intertwining phenomena occur in the presence of poly-nuclear aluminum hydrolysis species and the polyelectrolyte during floc formation and growth.

\section{ACKNOWLEDGMENTS}

The author would like to thank Martin Carney, Michael Quille, Mbakure Johnson and Stephen Conlon for carrying out the geotechnical test program at Trinity 
College Dublin. The author also acknowledges the assistance of Michael Quille in preparing some of the figures contained in this paper and Robbie Goodhue for interpreting the XRD analysis.

\section{REFERENCES}

1) Babatunde, A. O. and Zhao, Y. Q. (2007): Constructive approaches toward water treatment works sludge management: an international review of beneficial reuses, Environmental Science and Technology, 37(2), 129-164.

2) BS1377 (1990a): Methods of Test for Soils for Civil Engineering Purposes. Part 2: Classification Tests, British Standards Institution, London.

3) BS1377 (1990b): Methods of Test for Soils for Civil Engineering Purposes. Part 8: Shear Strength Tests (Effective Stress), British Standards Institution, London.

4) O'Kelly, B. C. (2004): Accurate determination of moisture content of organic soils using the oven drying method, Drying Technology, 22(7), 1767-1776.

5) O'Kelly, B. C. (2008a): Development of a large consolidometer-permeameter apparatus for testing soft soils, Proceedings, ASCE Geo Congress on the Challenge of Sustainability in the Geoenvironment, New Orleans, USA, 9th-12th March, 5, 60-67.

6) O'Kelly, B. C. (2008b): Geotechnical properties of a municipal water treatment sludge incorporating a coagulant, Canadian Geotechnical Journal, 45(5), 715-725.

7) O'Kelly, B. C. (2009): Development of a large consolidometer apparatus for testing peat and other highly organic soils, $S U O-$ Mires and Peat, 60(1/2), 23-36.

8) O'Kelly, B. C. and Quille, M. E. (2009): Compressibility and consolidation of water treatment residues, Waste and Resource Management: Proceedings of the Institution of Civil Engineers, 162(WR2), 85-97.

9) O'Kelly, B. C. (2010): Landfill disposal of alum water treatment residues: some pertinent geoengineering properties, Residuals Science and Technology, 7(2), 95-113.

10) O'Kelly, B. C. and Quille, M. E. (2010): Shear strength properties of water treatment residues, Geotechnical Engineering: Proceedings of the Institution of Civil Engineers, 163(GE1), 23-35.

11) Tchobanoglous, G., Burton, F. L. and Stensel, H. D. (2003): Wastewater Engineering, Treatment and Reuse, 4th ed., McGrawHill, New York.

12) Turchiuli, C. and Fargues, C. (2004): Influence of structural properties of alum and ferric flocs on sludge dewaterability, Chemical Engineering, 103(1/3), 123-131.

13) Twort, A. C., Ratnayaka, D. D. and Brandt, M. J. (2000): Water Supply, 5th ed., Arnold, London.

14) Wang, M. C., Hull, J. Q., Jao, M., Dempsey, B. A. and Cornwell, D. A. (1992): Engineering behavior of water treatment sludge, ASCE Journal of Environmental Engineering, 118(6), 848-864.

15) Wang, M. C. and Tseng, W. (1993): Permeability behavior of a water treatment sludge, ASCE Journal of Geotechnical Engineering, 119(10), 1672-1677.

16) Wu, C. C., Huang, C. and Lee, D. J. (1997): Effects of polymer dosage on alum sludge dewatering characteristics and physical properties, Colloids and Surfaces A: Physicochemical and Engineering Aspects, 122(1/3), 89-96. 